\title{
Effects of a lateral row anchor position on the suture holding strength of a double-row knotless fixation in rotator cuff repair
}

\author{
Rotator manşet onarımında lateral sıra kanca konumunun çift sıra dügümsüz tespitte \\ sütür tutma gücüne etkisi
}

\author{
Ahmet Emrah Acan, MD, ${ }^{1}$ Onur Hapa, MD, ${ }^{2}$ Levent Horoz, MD, ${ }^{2}$ \\ Aylin Kara, MD, ${ }^{3}$ Hasan Havıtçıoğlu. MD ${ }^{2}$

\begin{abstract}
'Department of Orthopedics and Traumatology, Muğla Sıtkı Koçman University Training and Research Hospital, Muğla, Turkey
${ }^{2}$ Department of Orthopedics and Traumatology, Medical Faculty of Dokuz Eylül University, İzmir, Turkey

${ }^{3}$ Department of Biomechanics, Dokuz Eylül University, İzmir, Turkey
\end{abstract}

\begin{abstract}
Objectives: This study aims to evaluate the effects of anchor positions on the suture holding strength of a double-row knotless fixation in rotator cuff repair.

Materials and methods: Four different double-row fixation techniques were assessed. In group 1, a 15-mm-wide mattress suture was fixed using a knotless lateral row anchor, horizontal to the shaft. In group 2, the medial sutures were fixed with a $5-\mathrm{mm}$ more lateral anchor that was placed at $45^{\circ}$ to the long axis of the humeral shaft. In group 3, different from group 2, medial sutures were fixed with a $30-\mathrm{mm}$ mattress suture width. In group 4, the mattress sutures coming from the medial row anchors were fixed to the $10-\mathrm{mm}$ more lateral row, vertical to the long axis of the humeral shaft. The specimens were cyclically loaded from $10 \mathrm{~N}$ to $30 \mathrm{~N}$ at $0.5 \mathrm{~Hz}$ for 50 cycles, and then loaded to failure.
\end{abstract}

Results: Group 4 had higher cyclic elongation values than group $1(\mathrm{p}=0.021)$ and group $3(\mathrm{p}=0.006)$. Group 1 had lower maximum load value than group $3(\mathrm{p}=0.011)$. Most of the specimens failed with suture ruptures. Unlike the other groups, none of the specimens in group 4 failed via a suture pull through the lateral anchor.

Conclusion: A horizontal lateral row anchor positioned closer to the medial anchor resulted in less cyclic elongation when compared to a more vertically positioned lateral row anchor. The vertical or oblique positioning of the lateral row anchor did not result in any increase in the failure load value; however, the vertical placement prevented a suture pull through the lateral row anchor.

Keywords: Biomechanics; double-row; rotator cuff. öz

Amaç: Bu çalışmada, rotator manşet onarımında çift sıra düğümsüz tespitte kanca pozisyonlarının, sütür tutma gücü üzerindeki etkileri değerlendirildi.

Gereç ve yöntemler: Dört farklı çift sıra tespit tekniği değerlendirildi. Grup 1'de 15 mm genişliğindeki matris sütür, düğümsüz lateral kanca ile şafta yatay olarak; grup 2'de medial sütürler $5 \mathrm{~mm}$ daha lateraldeki kanca ile ve humerus şaftı uzun aksına $45^{\circ}$ yerleştirilmiş olarak; grup 3'te grup 2'den farklı olarak matris sütür genişliği $30 \mathrm{~mm}$ olarak; grup 4'te medial sıra kancalarından gelen matris sütürler, $10 \mathrm{~mm}$ daha lateral sırada ve humerus şaftı uzun aksına dikey olacak şekilde tespit edildi. Spesimenler periyodik olarak 10 N'dan $30 \mathrm{~N}$ 'a $0.5 \mathrm{~Hz}$ 'de 50 siklus yüklendi ve sonra başarısızlığa yüklendi.

Bulgular: Grup 4'te grup $1(\mathrm{p}=0.021)$ ve grup 3'e $(\mathrm{p}=0.006)$ göre daha yüksek siklik uzama değerleri vardı. Grupl'de grup 3'e göre daha düşük maksimum yük değeri vardı $(p=0.011)$. Çoğu spesimen sütür yırtılması ile başarısızlığa uğradı. Diğer grupların aksine, grup 4'teki spesimenlerin hiçbiri lateral kancadan sütür sıyrılması şeklinde başarısızlığa uğramadı.

Sonuç: Yatay lateral sıra kanca medial kancaya daha yakın konumlandırıldığında, daha dikey konumlandırılan lateral sıra kancaya göre daha az siklik uzama ile sonuçlandı. Lateral sıra kancanın dikey veya eğimli konumlandırılması, başarısızlık yük değerinde herhangi bir artış ile sonuçlanmadı, fakat dikey yerleşim lateral sıra kancadan sütür sıyrılmasını engelledi.

Anahtar sözcükler: Biyomekanik; çift sıra; rotator manşet.

- Received: September 26, 2017 Accepted: February 08, 2017

- Correspondence: Ahmet Emrah Acan, MD. Muğla Sıtkı Koçman Üniversitesi Eğitim ve Araştırma Hastanesi Ortopedi ve Travmatoloji Kliniği, 48000 Menteşe, Muğla, Turkey. Tel: +90 507 - 7724362 e-mail: dremrahacan@hotmail.com 
A recent development in arthroscopic rotator cuff repair has been the transosseous equivalent suture bridge repair. ${ }^{[1]}$ The advantages of this method include a larger footprint, greater initial construct strength, and a larger tendon-bone interface. ${ }^{[1,2]}$ One major drawback is clinical failure, which may occur as a medial re-rupture at the musculotendinous junction. This is not the case for a traditional singlerow repair, but is the case for the recent transosseous equivalent suture bridge repair technique. In order to overcome this problem, the knotless double-row repair technique has been developed. However, this system is not without its problems, since there is often a sense of suture loosening and/or the backup of lateral row anchors or sutures, possibly due to the lower bone strength of the greater tubercle..$^{[3-6]}$ Denard and Burkhart ${ }^{[7]}$ described a rescue anchor technique to be used when the medial row anchor fixation seems insecure. In this technique, the sutures from the medial anchor are fixed at the lateral part of the greater tubercle (vertical to the humerus shaft axis) with the main purpose of load distribution, rather than footprint compression. The lateral cortex is stronger than the footprint. ${ }^{[7,8]}$

In this study, we aimed to evaluate the effects of a lateral row anchor position and the width of the medial mattress sutures on the suture holding strength of a double-row knotless fixation in a rotator cuff repair. ${ }^{[9]}$ The hypothesis was that a more lateral positioning of the lateral anchor (vertical to the humerus shaft) would be stronger than two medial positions (with the footprint parallel to the shaft or at the tip of the greater tubercle, $45^{\circ}$ to the long axis of the shaft), with less suture pull-out through the lateral row anchor. Additionally, it was hypothesized that increasing the width of the medial mattress sutures would decrease the strength of the construct, leading to an increased incidence of suture pull-out from the lateral knotless anchor.

\section{MATERIALS AND METHODS}

This study was conducted at Dokuz Eylül University between January 2017 and March 2017. Mechanical testing was performed on 28 fourthgeneration identical humerus bones made from polyurethane foam with 10 pound per cubic foot (pcf) density (Sawbones; Pacific Research Laboratories Inc., Vashon, Washington, USA). The bones were separated into four groups of seven for the four types of testing: horizontal, oblique, oblique wide mattress, and vertical (Figure 1). For the reconstructions, bovine infraspinatus tendons pound per cubic foot value were retrieved from the shoulders of abattoir carcasses within 48 hours of death. The specimens were screened and excluded if there were any macroscopic signs of degeneration (a)
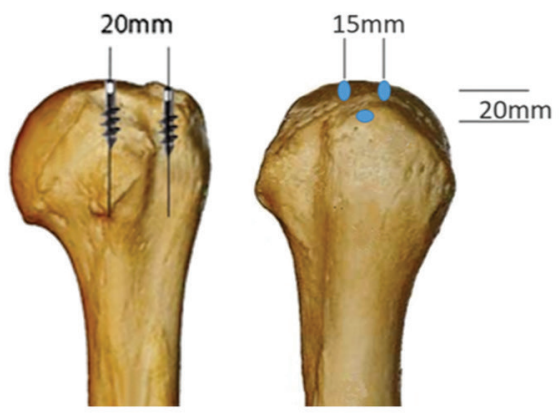

(c)

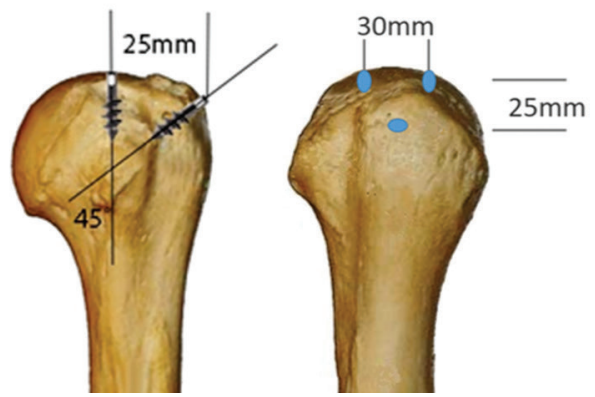

(b)

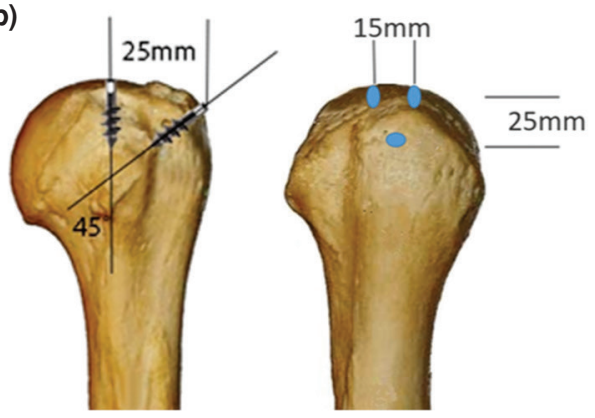

(d)

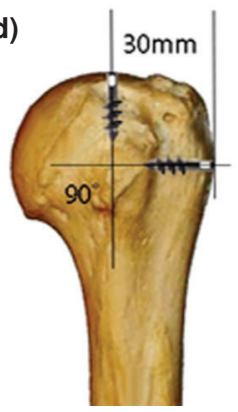

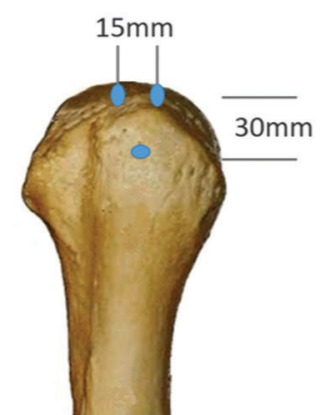

Figure 1. Anchor positions: (a) group 1 (20 mm between medial and lateral row anchors, width of suture mattress $15 \mathrm{~mm}$ ), (b) group 2 (25 mm between medial and lateral row anchors, width of suture mattress $15 \mathrm{~mm}$ ), (c) group 3 (25 mm between medial and lateral row anchors, width of suture mattress $30 \mathrm{~mm}$ ), and (d) group 4 (30 mm between medial and lateral row anchors, width of suture mattress $15 \mathrm{~mm}$ ). 
or evidence of trauma-related injury. All of the specimens were frozen immediately after harvesting and stored at $-20^{\circ} \mathrm{C}$ until use. Before testing, the specimens were thawed at room temperature for 24 hours, soaked in wet gauze until testing and none of the specimens were excluded during this test. The tendon thickness was measured using a digital caliper on all of the specimens. A $5.5 \mathrm{~mm}$ Healix Ti medial anchor (DePuy Mitek Inc., Raynham, MA, USA) and a $4.75 \mathrm{~mm}$ knotless Healix Advance lateral anchor (DePuy Mitek Inc., Raynham, MA, USA) were used. The four treatment groups were as follows:

- Group 1 (horizontal): A $15 \mathrm{~mm}$ wide mattress suture $20 \mathrm{~mm}$ from the lateral edge of the tendon, fixed $20 \mathrm{~mm}$ lateral to the medial anchor, using a knotless lateral row anchor, horizontal to the shaft.

- Group 2 (oblique): The medial sutures $(15 \mathrm{~mm}$ mattress) were fixed with a lateral anchor that was placed $25 \mathrm{~mm}$ lateral to the medial anchor, at $45^{\circ}$ to the long axis of the humerus shaft.

- Group 3 (wide): The same as group 2, but with a $30 \mathrm{~mm}$ mattress suture width.

- Group 4 (vertical): The $15 \mathrm{~mm}$ mattress sutures from the medial row anchor were fixed to the lateral row, $30 \mathrm{~mm}$ lateral to the first medial anchor, vertical to the long axis of the humerus.

The biomechanical testing was performed with each humerus secured at the shaft to a custom-made clamp, with the long axis of the humerus placed at $135^{\circ}$ to the actuator arm (Figure 2). This created an orthogonal or anatomical pull direction. At $3 \mathrm{~cm}$ proximal to the medial fixation site, the tendon was secured to the soft tissue holding clamp of the materials testing system (AG-I, $10 \mathrm{kN}$; Shimadzu, Kyoto, Japan). A 5-N preload was applied for 5 seconds to each specimen, and each specimen was then cyclically loaded from $10 \mathrm{~N}$ to $30 \mathrm{~N}$ at $0.5 \mathrm{~Hz}$ for 50 cycles. Following the cyclic loading, each tendon specimen was then loaded up to the failure point at a constant rate of $1 \mathrm{~mm} /$ second. $^{[10]}$

The load in Newtons and amount of displacement in millimeters were recorded until failure. The peak-to-peak displacement and elongation were determined during cyclic testing. The elongation was the difference in the y-displacement between the first cycle peak and the $50^{\text {th }}$ cycle peak. The average of the peak-to-peak displacement values of the $48^{\text {th }}, 49^{\text {th }}$, and $50^{\text {th }}$ cycles was used for the analysis, and the ultimate tensile load was considered to be the peak force. The stiffness was calculated by determining the slope of the loaddisplacement curve using a best-fit line on the load versus displacement curve. The peak-to-peak displacement $(\mathrm{mm})$, cyclic elongation $(\mathrm{mm})$, ultimate load $(\mathrm{N})$, stiffness $(\mathrm{N} / \mathrm{mm})$, and failure mode were recorded for each specimen.

\section{Statistical analysis}

The data analysis was performed using the Statistical Package for the Social Sciences for Windows, version 11.5 (SPSS Inc., Chicago, IL, USA). The distribution of the data was analyzed using the Kolmogorov-Smirnov test and the Shapiro-Wilk test. A one-way analysis of variance was used to detect any differences in the variables between the different groups. When a difference was detected for a given variable, the Games-Howell test was used to compare the groups with one variable in order to detect the source of the difference. A $p$ value of $<0.05$ was considered to be statistically significant. Finally, a post hoc power analysis using PASS software (NCSS Statistical Software, Kaysville, UT, USA) demonstrated that the measured observed power was 0.196 for the peak-to-peak displacement, 0.895 for the cyclic elongation, 0.800 for the ultimate load, and 0.308 for the stiffness.

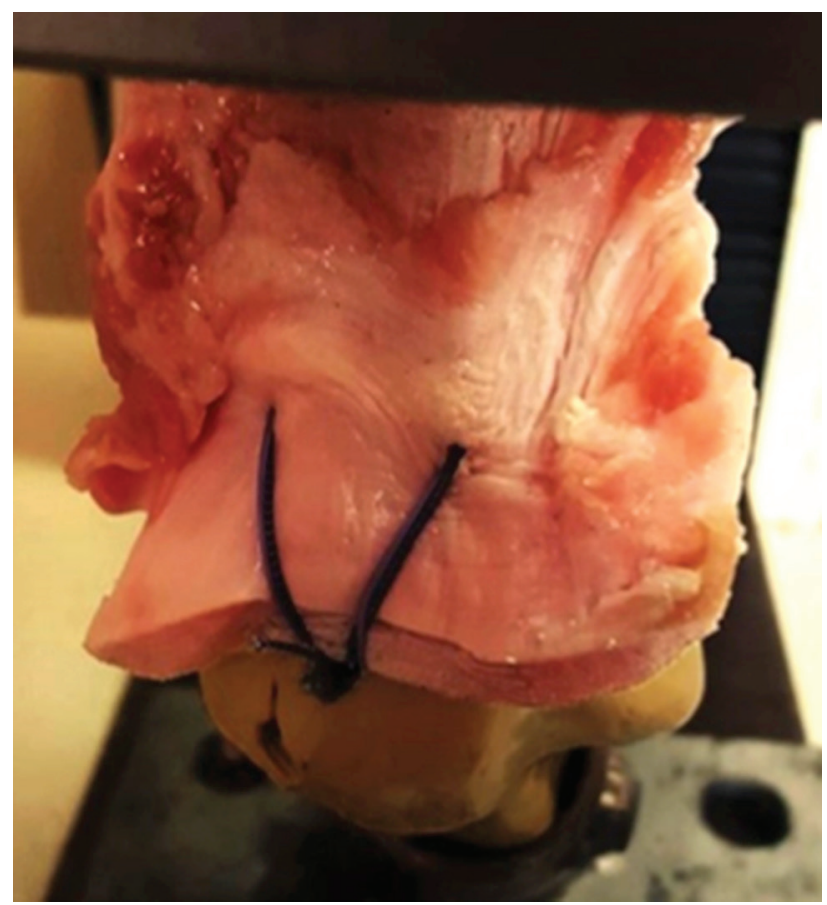

Figure 2. Test set-up of specimen belonging to group 1 (lateral row anchor parallel to shaft and with $15 \mathrm{~mm}$ width of medial suture mattress). 


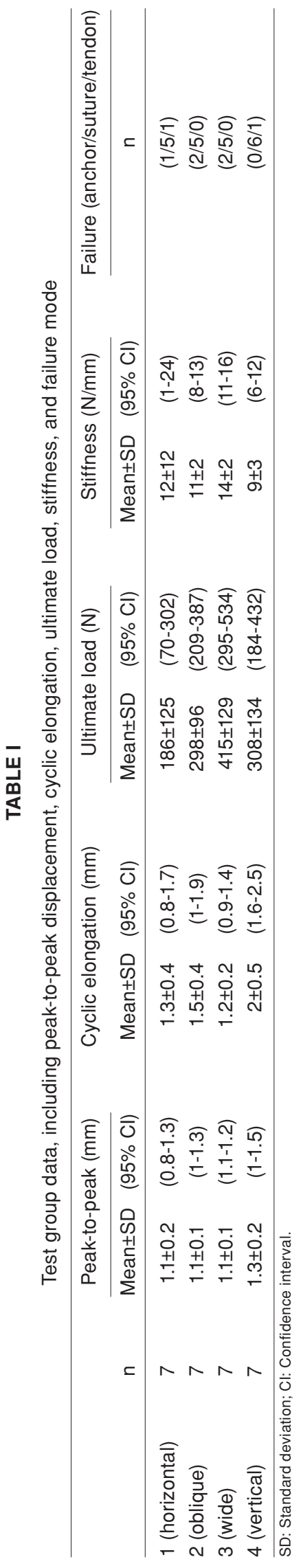

\section{RESULTS}

No difference was seen between the groups with respect to the mean thickness of the tendon $(0.7 \pm 0.1 \mathrm{~mm}, \mathrm{p}>0.05)$. The mean peak-to-peak displacement, elongation during cyclic loading, ultimate failure load, and stiffness, as well as the standard deviation, 95\% confidence interval, failure modes, and comparisons between the groups are shown in Table I. Group 4 (vertical) had a higher cyclic elongation value than group $1(p=0.021)$ and group $3(p=0.006)$, while group 1 had a lower ultimate load than group $3(\mathrm{p}=0.011)$. Most of the specimens failed with a suture rupture, while the others failed because the suture cut through the tendon or there was suture slippage through the anchor.

\section{DISCUSSION}

The main finding of the present study was that a lateral anchor fixation closer to the medial anchor and parallel or horizontal to the shaft resulted in less cyclic elongation than when the lateral anchor was placed laterally and vertical to the shaft of the humerus. The increase in the width of the mattress suture did not result in any decrease in the strength or a different failure mode. There was no failure in the oblique groups caused by the suture cutting through the tendon or in the vertical group by suture slippage through the anchor.

Denard and Burkhart ${ }^{[7]}$ described a rescue anchor technique to be used when the medial row anchor was believed to be loose. In this particular technique, the medial sutures from the loose medial anchor are fixed with an additional lateral anchor that is placed more laterally than the traditional lateral row of a double-row fixation. This is similar to the method applied in group 4 of the current study, which was dependent on the lateral cortex being stronger than the rotator footprint. The assumed advantage was to increase the load distribution rather than the footprint compression. ${ }^{[8]}$

In a clinical setting, Kummer et al. ${ }^{[11]}$ reported that the suture legs from the medial row anchor secured with the first lateral row anchor appeared to loosen when the other lateral row anchors were inserted into the remaining sutures. However, this was not observed in the biomechanical testing; therefore, it was concluded that the clinical cases of observed loosening were due to anchor fixation failure. The suture loosening $(0.1-1 \mathrm{~mm})$ resulted from an insignificant lateral tendon laxity or lift off $(0.004 \mathrm{~mm})$ after cyclic loading. Moreover, the failure mode was the medial movement $(2.5-5 \mathrm{~mm})$ of the lateral edge of the tendon, probably due to the creeping of the suture 
or tendon tissue, slippage of the suture through the anchor, or tightening of the medial mattress.

Similarly, Esen et al. ${ }^{[12]}$ reported increased initial strength of two-part osteoporotic neck fracture fixation of the proximal humerus when multiplanar $\mathrm{K}$ wire fixation is used including the lateral cortex of the proximal humerus compared to uni-planar fixation only through the greater tuberosity..$^{[12]}$

In the recent report of Barber et al..$^{[13]}$ in which the Healix Br (DePuy Mitek Inc., Raynham, MA, USA) anchor was biomechanically tested, the failure load of $110 \mathrm{~N}$ was lower than our results, and the displacement of $6 \mathrm{~mm}$ was higher than the 1.5-2 $\mathrm{mm}$ displacement in the present study. Most of the specimens were failed by suture slippage while the failure was due to suture rupture in our study. However, the main difference was the tested osteoporotic cadaver bones with a distinct testing protocol.

In the present study, the failures on the medial row by suture cut through from the tendons might be caused by the excessive tensioning of the lateral row. Even though it was not found vulnerable in the report of Dierckman et al., ${ }^{[14]}$ surgeons must pay attention when using peek lateral anchors.

In the present study, the cyclic elongation values of the vertical group were determined to be higher than those of the horizontal group, which resulted in an up to $2.5 \mathrm{~mm}$ elongation, which was similar to the findings reported in the previous biomechanical study. ${ }^{[1]}$ This demonstrated that the construct laxity was dependent on the distance of the lateral anchor relative to the medial anchor, rather than the position of the lateral anchor. Therefore, both hypotheses of this study were rejected. The increase in the width of the mattress suture did not result in any decrease in the strength or a different failure mode. Moreover, the oblique or vertical positioning did not result in a statistically significant increase in the ultimate load, although this might be different in an osteoporotic bone model. Only the oblique positioning with an increased width resulted in an increase in the failure load when compared to the horizontal group. Whether this was due to the combined effect of the width of the mattress with the oblique anchor remains unclear. A second interesting point was the failure mode. There was no failure in the oblique groups caused by the suture cutting through the tendon or in the vertical group by suture slippage through the anchor. However, the oblique and horizontal groups failed via a suture pulling through the lateral row anchor.

There were several limitations to this study, primarily in the fact that a Sawbone model of the humerus was used. The use of a cadaver humerus would present non-homogeneous materials, such as different states of osteoporosis, dimensions, genders, and ages, which could prevent the standardization of the configurations as tested in the present study. However, the main purpose of this study was to evaluate the suture holding strength of the lateral row anchor, instead of the anchor holding strength of the bone. In addition, the tendon specimens were fresh frozen, the test was not performed in vivo, it was a "time zero" study, and it did not reveal the changes that could occur over time. The use of seven specimens per group, although consistent with previous biomechanical studies, might also have limited the power of this study. Moreover, the fact that most of the specimens failed by suture rupture indicated the suture strength, not the strength of the whole configuration.

In conclusion, this study showed that the horizontal lateral row anchor positioned closer to the medial anchor resulted in less cyclic elongation when compared to a more vertically positioned lateral row anchor. The vertical or oblique positioning of the lateral row anchor did not result in any increase in the failure load. However, the specimens tended to fail via suture pulling through the lateral row when it was obliquely or horizontally placed at the humerus, unlike in vertical placement.

\section{Declaration of conflicting interests}

The authors declared no conflicts of interest with respect to the authorship and/or publication of this article.

\section{Funding}

The authors received no financial support for the research and/or authorship of this article.

\section{REFERENCES}

1. Park MC, Tibone JE, ElAttrache NS, Ahmad CS, Jun BJ, Lee TQ. Part II: Biomechanical assessment for a footprintrestoring transosseous-equivalent rotator cuff repair technique compared with a double-row repair technique. J Shoulder Elbow Surg 2007;16:469-76.

2. Park MC, ElAttrache NS, Tibone JE, Ahmad CS, Jun BJ, Lee TQ. Part I: Footprint contact characteristics for a transosseous-equivalent rotator cuff repair technique compared with a double-row repair technique. J Shoulder Elbow Surg 2007;16:461-8.

3. Barber FA, Drew OR. A biomechanical comparison of tendon-bone interface motion and cyclic loading between single-row, triple-loaded cuff repairs and double-row, suture-tape cuff repairs using biocomposite anchors. Arthroscopy 2012;28:1197-205.

4. Busfield BT, Glousman RE, McGarry MH, Tibone JE, Lee TQ. A biomechanical comparison of 2 technical variations of double-row rotator cuff fixation: the importance of medial row knots. Am J Sports Med 2008;36:901-6. 
5. Kaplan K, ElAttrache NS, Vazquez O, Chen YJ, Lee T. Knotless rotator cuff repair in an external rotation model: the importance of medial-row horizontal mattress sutures. Arthroscopy 2011;27:471-8.

6. Kirchhoff C, Braunstein V, Milz S, Sprecher CM, Fischer F, Tami A, et al. Assessment of bone quality within the tuberosities of the osteoporotic humeral head: relevance for anchor positioning in rotator cuff repair. Am J Sports Med 2010;38:564-9.

7. Denard PJ, Burkhart SS. Techniques for managing poor quality tissue and bone during arthroscopic rotator cuff repair. Arthroscopy 2011;27:1409-21.

8. Rossouw DJ, McElroy BJ, Amis AA, Emery RJ. A biomechanical evaluation of suture anchors in repair of the rotator cuff. J Bone Joint Surg [Br] 1997;79:458-61.

9. Atik OŞ. Are all case reports worth publishing? Eklem Hastalik Cerrahisi 2016;27:61.

10. Awwad GE, Eng K, Bain GI, McGuire D, Jones CF. Medial grasping sutures significantly improve load to failure of the rotator cuff suture bridge repair. J Shoulder Elbow Surg 2014;23:720-8.

11. Kummer F, Hergan DJ, Thut DC, Pahk B, Jazrawi LM. Suture loosening and its effect on tendon fixation in knotless double-row rotator cuff repairs. Arthroscopy 2011;27:1478-84.

12. Esen E, Doğramaci $Y$, Kömürcü M, Kanatli U, Bölükbaşi $S$, Atahan AO. Biomechanical comparison of fixation of twopart osteoporotic neck fracture of the proximal humerus using uni-planar and multi-planar Kirschner wire. Eklem Hastalik Cerrahisi 2009;20:114-8.

13. Barber FA, Bava ED, Spenciner DB, Piccirillo J. Cyclic biomechanical testing of biocomposite lateral row knotless anchors in a human cadaveric model. Arthroscopy 2013;29:1012-8.

14. Dierckman BD, Goldstein JL, Hammond KE, Karas SG. A biomechanical analysis of point of failure during lateral-row tensioning in transosseous-equivalent rotator cuff repair. Arthroscopy 2012;28:52-8. 